\title{
Study of Implication of Qualification and Experience in Perception of Risks and Barriers for Innovative Projects
}

\author{
Balkrishna E. Narkhede \\ Industrial Engineering and Manufacturing Systems \\ National Institute of Industrial Engineering (NITIE) \\ Vihar Lake, NITIE, Powai, Mumbai, Maharashtra, India \\ Corresponding author: benarkhede1@gmail.com \\ Yogesh D. Ghadage \\ Department of Production Engineering \\ Veermata Jijabai Technological Institute (VJTI) \\ H. R. Mahajani Road, Matunga, Mumbai, Maharashtra, India \\ E-mail: yghadage@gmail.com \\ Rakesh D. Raut \\ Operations and Supply Chain Management \\ National Institute of Industrial Engineering (NITIE) \\ Vihar Lake, NITIE, Powai, Mumbai, Maharashtra, India \\ E-mail: rakeshraut09@gmail.com; rraut@nitie.ac.in \\ Sunil Luthra \\ Department of Mechanical Engineering \\ State Institute of Engineering \& Technology \\ (Formerly known as Government Engineering College) \\ Nilokheri, Haryana, India \\ E-mail: sunilluthra1977@gmail.com
}

(Received September 12, 2018; Accepted November 24, 2018)

\begin{abstract}
Risks and barriers identification and management in innovative projects is a crucial phase. The risk and barrier evaluation is a critical task for the risk manager. The correctness of the evaluation process leads to effective management of risks and barriers. Effective management of risks and barriers improve the probability of success rate of the innovative projects. The current study attempt to understand the effect of Qualification \& Experience (QE) in the perception of risks and barriers. This study intends to conclude on the effect of the above factors in the evaluation process. The evaluation of outcome indicates that the QE factors have their independent perception in the risk and barrier evaluation process.
\end{abstract}

Keywords- Risk management, Barriers, Innovative projects, ANOVA.

\section{Introduction}

Innovation is the inexhaustible motive force for the prosperity of a nation, and also the life source of an enterprise. Innovation plays a role of soul in the nation's progress (Guo, 2013). Corporate growth can be achieved through technological innovation (Teece, 1986; Wang et al., 2010). Quality of the products are improved by means of innovation with a reduced price (Hernandez-Gonzalez et al., 2014). However, in the innovation high risks and barriers are involved. To achieve the goal of 
International Journal of Mathematical, Engineering and Management Sciences

Vol. 4, No. 2, 289-305, 2019

https://dx.doi.org/10.33889/IJMEMS.2019.4.2-024

the innovation, managers need to implement scientific and effective innovation risk management and barrier management processes.

Project risk is an uncertain event which causes damage or loss. Project risks are threatening as it has an effect on the project objectives such as schedule, cost, and quality (Zwikael and Sadeh, 2007; Zwikael et al., 2014). During the execution of the innovative project, various uncertainties are arises. To meet the goal of these projects, the uncertainties need to be successfully tackled (Teberga and Oliva, 2018). Few problems/ risks are not effectively found until they release themselves (Oliva et al., 2011; Oliva, 2014; Teberga and Oliva, 2018). In the initial stage of the project, project managers have the least knowledge of risks involved. This may result in project delay, overrun of the project budget and the degradation of project quality (Zwikael and Ahn, 2011; Zhang and Fan, 2014; Ajmal et al., 2017) underline the importance of risk identification, risk planning, risk analysis, and risk mitigation. According to Ajmal et al. (2017), risk management plays important role in successful execution. Risk management is an integral part of project management (Isaac, 1995; Elkington and Smallman, 2002). Risk management techniques reduce the expenditure and it also helps to expedite the project (Mu et al., 2009; Bowers and Khorakian, 2014).

Identification and evaluation of barriers is an equally important task to improve the success rate of innovative projects. It is essential to identify the hurdles/ barriers for innovative project management. It is required to identify those hurdles that result in failure to introduce new products/ processes. This provides crucial insights to the managers, to inform corporate strategies oriented to overcoming the obstacles to innovation. Two approaches can be applied to study the factors which are affecting on the innovation activities. These are innovation drivers and innovation barriers (Damanpour, 1991; Cloutier, 2012). The barrier approach is less focused research stream than the driver approach. The barrier approach is mainly useful as it enables the identification of specific bottlenecks among the many factors potentially affecting the innovation process.

To deal with the subject of risk and barriers it is utmost important of perception of the risks and barriers by the evaluators. The evaluation of the risks and barriers is a critical step in the process of risk and barrier analysis. The outcome of the analysis depends on the evaluation. Hence the evaluation process should be correct and error-free to lead to the correct output of the analysis. In this study authors have studied the effect of Qualification and Experience (QE) of the evaluator on the risk and barriers perception. The expected outcome of the study was formulating the effect of $\mathrm{QE}$ in the perception of the risks and barriers. The outcome will help in dealing with risk \& barriers and which intern results in a better perception of the risks and barriers (Santos and Cabral, 2008).

Following section deals with a literature review which covers definitions of innovation, risk, barriers, identification and evaluation of risks and barriers. The third section elaborates the methodology of the study and data collection for this research. Section four covers the methodology of the study. The fifth section contains the calculations. The discussion section is covered after calculations. The seventh section contains conclusions. The last section covers the limitations of study and scope for future research.

\section{Literature Review}

\subsection{Innovative Projects}

The term "innovation" is a Latin word, it means renewal (Schumpeter, 1934; Rudnik and Deptula, 2015). Innovation can be defined as any newly developed idea, practice which produces improved technology and superior methods of doing things. New concepts are adopted for projects, products 
International Journal of Mathematical, Engineering and Management Sciences

Vol. 4, No. 2, 289-305, 2019

https://dx.doi.org/10.33889/IJMEMS.2019.4.2-024

or services. Innovation adds value by improved features and quality manufacturing. It also improves profit by minimizing the cost (Banerjee et al., 2011). A project is a series of related activities with a well-defined set of desired end results (Fan et al., 2008; Dandage et al., 2018). In a project environment, the organisation structure is temporary and unique in nature (Palm and Lindahl, 2015; Dandage et al., 2018) Project management of innovative projects is defined as procedures with which the goal of the projects are achieved. In case of innovative project management huge efforts are required because of their inherent complex nature, the requirement of innovations, tight schedules and deeply reliant on expert judgment to maintain high quality \& performance (Santos and Cabral, 2008). Innovative projects are typically one of its kind. Successful project execution requires the successful tackling of uncertainties/ risks/ hurdles and the same are always a concern in academia and practice (Zhang, 2016).

\subsection{Project Risk}

Risk is a presence of potential or actual threats or opportunities that have an effect on the goal of the project during the life cycle. Risk can also be defined as an uncertain event or condition which if it occurs, has a positive or negative effect on the project goal (Dandage et al., 2018). According to Jannadi and Almishari (2003), the risk is a potential damage which may affect personnel or property. As per Sato and Hirao (2013), the risk is a probability of existing of the critical situation, where a particular activity cannot deliver mandatory output necessary for achieving the project goal no other alternatives available at that particular situation. Term uncertainty is proposed by Ward and Chapman (2003) instead of risk. It may be a threat or opportunity as well to the project. There are a lot of challenges in the execution of technologically innovative projects. Such projects inherently consist of risks, threats and uncertainties throughout the project lifecycle (Gassmann and Han, 2004; Luppino et al., 2014; Bowers and Khorakian, 2014).

\subsection{Project Barriers}

Barriers are nothing but the obstacles or bottlenecks. One of the several different approaches for innovation focusses on the barriers, to innovation generally as perceived by the top managers of the firms. This approach is occasionally extended to include factors inspiring innovation. Successful management of innovative projects is connected to managing risks and barriers (Kwak and LaPlace, 2005).

\subsection{Identification and Evaluation of Risk and Barriers}

Elkington and Smallman (2002) mentioned that risk and barrier identification is a key process in which the situation of the project is studied for the realization of what could go wrong at any point of time of project cycle. Once the risks are identified it is possible to take a corrective action to nullify or decrease its adverse impact (Marcelino-Sádaba et al., 2014). Similarly, barrier identification and overcoming the barriers is also an essential process. The risk and barrier sources and potential consequences are identified in advance prior to their occurrence (Ahmed et al., 2007). The process of identification of the risk \& barriers and nullifying its adverse effect is to be carried out throughout the lifecycle of the project (Stewart and Fortune, 1995; Turner et al. 2010).

Various risk and barriers analysis techniques determine the influence of risk and barriers factors on the project. It became easy to deal with risk and barriers when they are categorised. Various risks analysis techniques can be applied for project risk analysis. Probability and impact technique provides a simple format which shows the relative importance of risk events (Ahmed et al., 2007). Estimation of system reliability is a technique to determine the period for which the system will function without a failure (Ahmed et al., 2007). Fault tree analysis is a technique which determines 
International Journal of Mathematical, Engineering and Management Sciences

Vol. 4, No. 2, 289-305, 2019

https://dx.doi.org/10.33889/IJMEMS.2019.4.2-024

the chance or failure event occurring in the project. Event tree analysis is a technique which determines how likely a particular event represented on an event tree is likely to happen from an initial event. In a sensitivity analysis, the responses are affected if the project condition changes. Risk events are prioritized in risk evaluation. It helps to determine a risk mitigation plan. Risk mitigation plans are decided based on experience; lessons learned reports, best practices, company knowledge base, industry benchmarks and standard practices (Ahmed et al., 2007). Different risk evaluation techniques are utilised. Decision tree analysis is one of a technique for risk evaluation. In decision tree analysis decision nodes and chance, nodes are drawn graphically, and expected monetary values (EMV) are connected to the nodes. EMV is then utilised to calculate expected returns from decisions. The decision is selected which generate the maximum returns. Another technique is Portfolio management. In this technique, multiple projects are compared concerning risk in investment and returns. The data is used by the decision maker to decide on the strategy. One more technique is multiple criteria decision-making. In this method, different project attributes including the negative and positive factors of a decision are considered. Project attributes are weighted according to project predominance of the predefined criteria. The weighted score for a particular attribute is decided based on the product of the relative weight and the score for an attribute. The risks are evaluated based on the standard risk attribute (Ahmed et al., 2007).

While execution of the innovative projects it is important to identify the barriers by the firms and overcome the barriers. It helps to lead the project to success. Certain researchers stated that innovation barriers prevent innovative activities in the company, whereas according to others Witte (1977) they can be understood as hindrances which can be overcome with effort.

\subsection{Research Gap}

There are few weaknesses to the analysed approaches of risk and barrier management of innovative projects.

- The number of models proposed for the perception of risk and barriers by evaluators for innovative projects are limited.

- The risk and barriers models proposed for innovative projects executed out of India cannot be applied as it is in Indian innovative project scenario.

- The perception of risk and barriers are missing in the Indian scenario.

In this study, relevant risks and barriers identified and are listed (refer Annexure 1 and Annexure 2). Total of 41 applicable risks and 10 applicable barriers are identified for study. The identification of the risks and barriers are carried out based on the literature review and validated by experts.

\section{Scope and Objectives}

- To identify the various risk and barriers for innovative projects based on literature review and to be validated by experts in the field of innovative projects.

- To prepare a questionnaire and conduct a pilot study.

- Formulation of hypothesis considering experience and educational qualification of the evaluation team.

- Conduct the survey with evaluation team experts.

- Analysis of data and testing the hypothesis to understand the effect of experience and educational qualification of experts. 
International Journal of Mathematical, Engineering and Management Sciences

Vol. 4, No. 2, 289-305, 2019

https://dx.doi.org/10.33889/IJMEMS.2019.4.2-024

\section{Methodology}

This study aim to understand the implication of experience \& educational qualification of the respondent participating in the evaluation process. For further study, hypothesis are formulated and tested based on expert's responses.

The methodology followed in this study is as below (Figure 1):

- Study of literature related to risks and barriers for innovative projects in India and listing down the applicable risks and barriers.

- Validation of listed risks and barriers by subject experts.

- Formulation of perception hypothesis considering qualification \& experience.

- Preparation of questionnaire and pilot survey.

- Modification of questionnaire and final survey with risk and barriers evaluation executives.

- Data analysis and calculations.

- Interpretation of the results and discussion

- Conclusions, recommendations and suggestions for future study.

Extensive literature review and formulation of Risk list and Barrier list

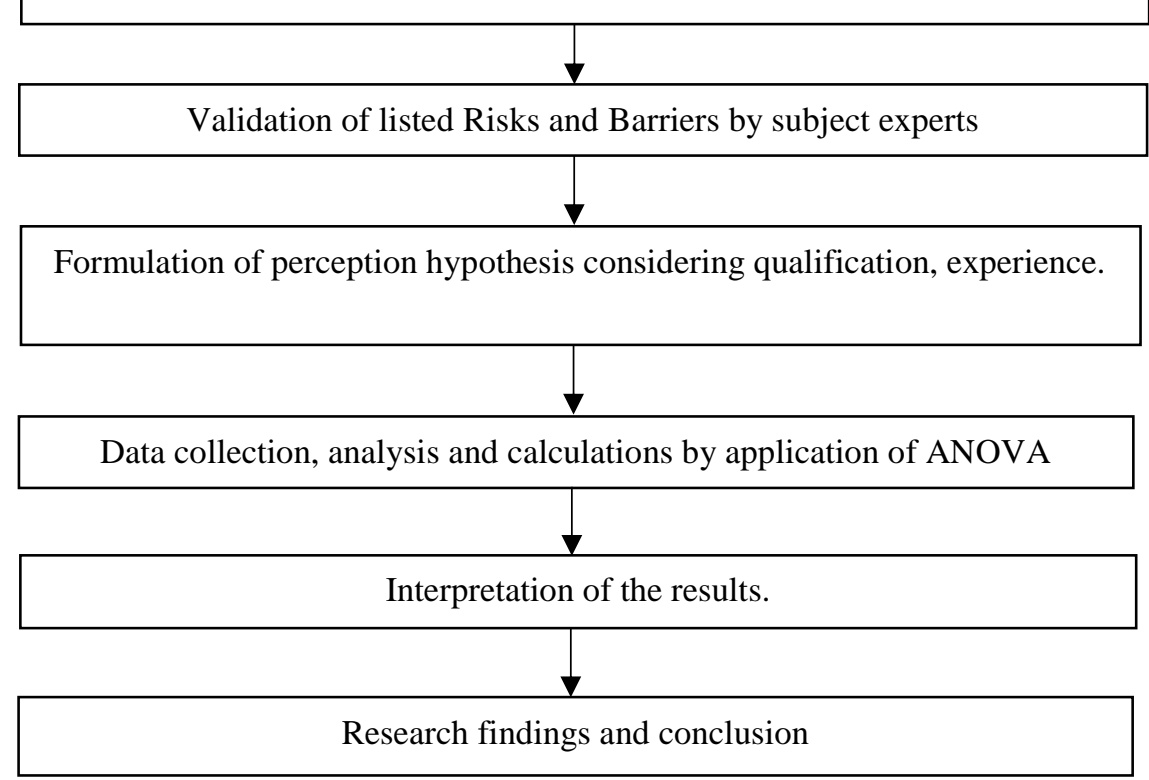

Figure 1. Research methodology

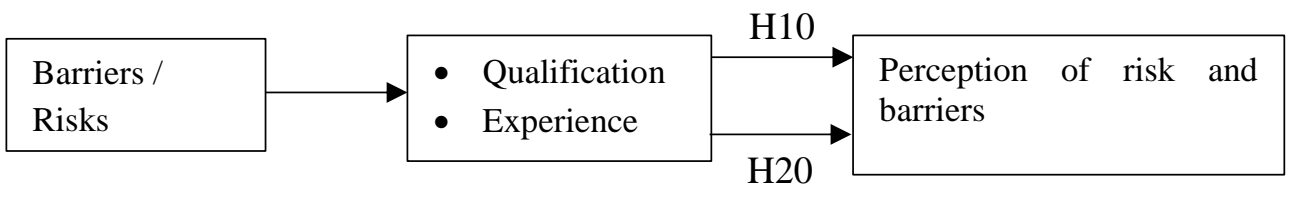

Figure 2. Research model 
International Journal of Mathematical, Engineering and Management Sciences

Vol. 4, No. 2, 289-305, 2019

https://dx.doi.org/10.33889/IJMEMS.2019.4.2-024

\section{Hypothesis}

Following hypothesis are formulated in our study.

- H10: There is no significant difference in risk perception and barrier through qualifications.

- H11: There is a significant difference in risk perception and barrier through qualifications.

- H20: There is no significant difference in risk perception and barrier through experience.

- H21: There is a significant difference in risk perception and barrier through experience.

The formulation of the hypothesis model is shown in Figure 2.

\subsection{Survey}

The validated list of risks and barriers are provided in the Annexure-1 and Annexure-2. The risks are categorised into 13 subcategories. These are related to project, design, finance quality, labour, supplier, customer, consultant, material, governments, site, environment and miscellaneous. Survey questionnaire prepared and data collected from the experienced risk and barriers evaluation executives from the various innovative project. Authors also interviewed senior project executives to understand the insights of the projects. The questionnaire is divided into three parts. The first part consists of general information of the respondent. In this section data like name, qualifications, experience and age of the respondent are collected. The second part of the questionnaire captures the response of the experts on the probability of occurrence of the identified risk. The third part of the questionnaire captures the response on the probability of occurrence of the barriers for innovative projects.

While responding to the statements, respondents specify their level of agreement for the occurrence of particular risk or barriers. Five-point likart scale used for collecting responses for the probability of occurrence of risk and barrier. The level of occurrence of the risk/ barriers is defined as Very Low, Low, Medium, High and Very High. These responses are converted into numbers from 1 to 5 respectively for further calculations. The questionnaire was tested with a pilot survey for clarity, ease of use, the value of the information that could be gathered. The necessary modifications are carried out after the pilot survey. Total 41 risks and 10 barriers for innovative projects are studied. The survey was shared online with 273 participants. We received a response from 195 respondent and 194 responses are further considered for the study. One response ignored due to duplication. The total score of each risk and barriers calculated by adding the responses of 194 respondents. Based on the score top 5 risks and top 2 barriers identified for hypothesis testing.

\subsection{The Analysis of Variance (ANOVA) and Calculations}

The analysis of variance (ANOVA) was developed to allow a researcher to test hypotheses about two or more conditions. ANOVA is a technique for analyzing experimental data in which one or more response (or dependent) variables are measured under various conditions identified by one or more classification variables. The combinations of levels for the classification variables form the cells of the experimental design for the data. An analysis of variance constructs tests to determine the significance of the classification effects. A typical goal in an analysis of variance is to compare means of the response variable for various combinations of the classification variables. ANOVA is a form of statistical hypothesis testing mainly used in the analysis of experimental data. A test result (calculated from the null hypothesis and the sample) is called statistically significant if it is deemed unlikely to have occurred by chance, assuming the truth of the null hypothesis. A statistically significant result, when a probability (sigma-value) is less than a pre-specified threshold (significance level), justifies the rejection of the null hypothesis, but only if the probability of the 
null hypothesis is not high. In the typical application of ANOVA, the null hypothesis is that all groups are random samples from the same population. For example, when studying the effect of different treatments on similar samples of patients, the null hypothesis would be that all treatments have the same effect (perhaps none). Rejecting the null hypothesis is taken to mean that the differences in observed effects between treatment groups are unlikely to be due to random chance.

Hypotheses: $\mathrm{H}_{0}$ : All population means are equal.

$\mathrm{H}_{\mathrm{A}}$ : At least two of the means differ.

Test Statistic:

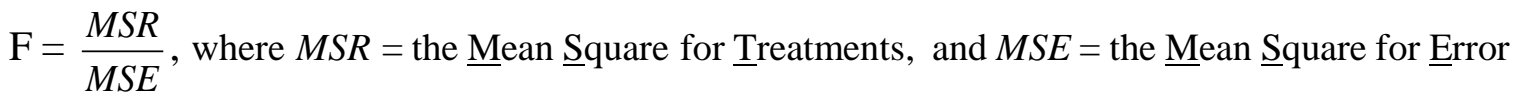

- The index $\mathrm{i}$ represents the $\mathrm{i}^{\text {th }}$ population or treatment, where $\mathrm{i}$ ranges from 1 to $k$

- The index $\mathrm{j}$ represents the $\mathrm{j}^{\text {th }}$ observation within a sample, where $\mathrm{j}$ ranges from 1 to $n_{\mathrm{S}}$

- $n$ is the total number of observations from all samples

- $y_{\mathrm{ij}}$ is the value of the $\mathrm{j}^{\text {th }}$ observation in the $\mathrm{i}^{\text {th }}$ sample

- $\bar{y}_{i}$ is the mean of the $i^{\text {th }}$ sample

$\overline{\bar{y}}$ is the mean of all $n$ observations, $\overline{\bar{y}}=\frac{1}{n} \sum_{i=1}^{k} \sum_{j=1}^{n_{S}} y_{i j}$, or the mean of the sample means $\overline{\bar{y}}=\frac{\bar{y}_{1}+\bar{y}_{2}+\cdots+\bar{y}_{k}}{k}$

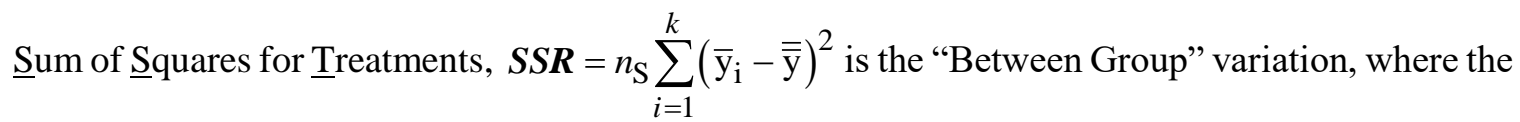
$k$ 'groups' or populations are represented by their sample means. If the sample means differ substantially then SST will be large.

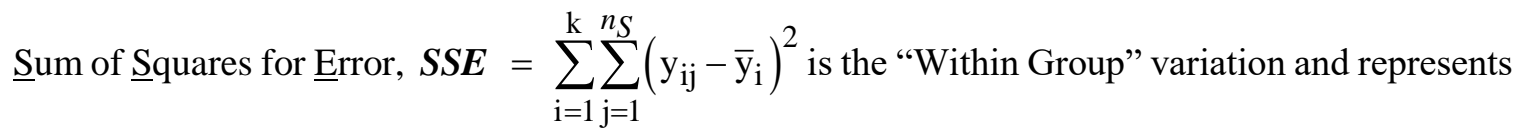
the random or sample-to-sample variation.

$\underline{\text { Total }} \underline{\text { Sum of }} \underline{\text { Squares, }} \boldsymbol{S S T}=\sum_{\mathrm{i}=1}^{\mathrm{k}} \sum_{\mathrm{j}=1}^{n_{S}}\left(\mathrm{y}_{\mathrm{ij}}-\overline{\overline{\mathrm{y}}}\right)^{2}$ is the total variation in the values of the response variables over all $k$ samples.

Degrees of freedom for treatments, $\mathrm{df}_{\mathrm{SSR}}=k-1$, Degrees of freedom for error, $\mathrm{df}_{\mathrm{SSE}}=n-k$, Total degrees of freedom, $\mathrm{df}_{\mathrm{SST}}=n-1$.

Mean $\underline{\text { Square for }}$ Treatments, $\boldsymbol{M S R}=\frac{\boldsymbol{S S R}}{k-1}$ is equivalent to MSR in regression. 
International Journal of Mathematical, Engineering and Management Sciences

Vol. 4, No. 2, 289-305, 2019

https://dx.doi.org/10.33889/IJMEMS.2019.4.2-024

Mean $\underline{\text { Square for } \underline{E} \text { rror, }} \boldsymbol{M S E}=\frac{\boldsymbol{S S E}}{n-k}$ is the same as MSE in regression. As in regression, MSE is an unbiased estimator of the common population variance $\sigma^{2}$.

The statistic used to test the null hypothesis $\mu_{1}=\mu_{2}=\ldots=\mu_{k}$ is $\boldsymbol{F}=\frac{\boldsymbol{M S R}}{\boldsymbol{M S E}}$.

If the null hypothesis is correct then this ratio should be close to one. If some of the sample means differ substantially, however, the ratio will be much larger. Large values of $\mathrm{F}$, therefore, correspond to strong evidence for rejecting $\mathrm{H}_{0}$.

\subsection{Profile of Respondents}

Demographical analysis \& results of the survey

Table 1. Qualification of the respondent

\begin{tabular}{|l|c|c|c|}
\hline & Frequency & Valid Percent & Cumulative Percent \\
\hline Undergraduate & 10 & 5.2 & 5.2 \\
\hline Graduate & 80 & 41.2 & 46.4 \\
\hline Postgraduate & 91 & 46.9 & 93.3 \\
\hline Doctorate & 13 & 6.7 & 100 \\
\hline Total & 194 & 100 & \\
\hline
\end{tabular}

Out of 194 respondents, $5.2 \%$ are undergraduate, $41.2 \%$ are graduate, $46.9 \%$ are postgraduate and $6.7 \%$ are doctorate (Table 1). The cumulative data shows that $87 \%$ of respondents are graduate. Hence highly qualified respondents have participated in this survey.

Table 2. Experience of the respondents

\begin{tabular}{|l|c|c|c|}
\hline & Frequency & Valid Percent & Cumulative Percent \\
\hline 0 to 15 years & 175 & 90.2 & 90.2 \\
\hline 16 to 40 years & 13 & 6.7 & 96.9 \\
\hline 41 to 50 years & 6 & 3.1 & 100.0 \\
\hline Total & 194 & 100.0 & \\
\hline
\end{tabular}

Out of 194 respondents, $90.2 \%$ have experience of 0 to 15 years, $6.7 \%$ have experience of 16 to 40 years and $3.1 \%$ have experience of 41 to 50 years (Table 2). There is a good mix of experience of people in the survey.

\section{Calculations}

5.1 As indicated in the methodology, the top 5 risks and 2 barriers are identified based on the likert responses (Table 3). The criterion applied is the total of likert's score.

Following Table shows the selected risks and barriers for further analysis. 
International Journal of Mathematical, Engineering and Management Sciences

Vol. 4, No. 2, 289-305, 2019

https://dx.doi.org/10.33889/IJMEMS.2019.4.2-024

Table 3. Identified risk and barriers

\begin{tabular}{|c|l|c|}
\hline Sr. No. & Risk & Total of Likert score \\
\hline 1 & Unrealistic time schedule resulting into the delay & 727 \\
\hline 2 & Frequent change in scope of work/ Nonclarity on the scope of work & 723 \\
\hline 3 & Operation cost overrun & 689 \\
\hline 4 & Monopoly of suppliers & 688 \\
\hline 5 & Corruption and bribery & 680 \\
\hline Sr. No. & Barrier & 708 \\
\hline 1 & Insufficient Resources & 701 \\
\hline 2 & Lack of motivation & \\
\hline
\end{tabular}

\subsection{Sigma Value for Hypothesis H10 and H11}

Calculations are carried out as indicated in the methodology and following are sigma value for hypothesis H10 and H11 (Table 4).

Table 4. Sigma for qualification

\begin{tabular}{|c|c|c|c|}
\hline Dependent Variable & $\begin{array}{l}\text { Qualification of the } \\
\text { respondent }\end{array}$ & $\begin{array}{l}\text { Qualification of the } \\
\text { respondent }\end{array}$ & Sigma \\
\hline \multirow{12}{*}{ Unrealistic time schedule resulting into delay } & \multirow{3}{*}{ Undergraduate } & Graduate & 0.998 \\
\hline & & Postgraduate & 0.926 \\
\hline & & Doctorate & 0.966 \\
\hline & \multirow{3}{*}{ Graduate } & Undergraduate & 0.998 \\
\hline & & Postgraduate & 0.299 \\
\hline & & Doctorate & 0.968 \\
\hline & \multirow{3}{*}{ Postgraduate } & Undergraduate & 0.926 \\
\hline & & Graduate & 0.299 \\
\hline & & Doctorate & 0.522 \\
\hline & \multirow{3}{*}{ Doctorate } & Undergraduate & 0.966 \\
\hline & & Graduate & 0.968 \\
\hline & & Postgraduate & 0.522 \\
\hline \multirow{12}{*}{$\begin{array}{l}\text { Frequent change in scope of work/ Nonclarity on the } \\
\text { scope of work }\end{array}$} & \multirow{3}{*}{ Undergraduate } & Graduate & 0.002 \\
\hline & & Postgraduate & 0.912 \\
\hline & & Doctorate & 0.775 \\
\hline & \multirow{3}{*}{ Graduate } & Undergraduate & 0.002 \\
\hline & & Postgraduate & 0.983 \\
\hline & & Doctorate & 0.231 \\
\hline & \multirow{3}{*}{ Postgraduate } & Undergraduate & 0.912 \\
\hline & & Graduate & 0.983 \\
\hline & & Doctorate & 0.152 \\
\hline & \multirow{3}{*}{ Doctorate } & Undergraduate & 0.775 \\
\hline & & Graduate & 0.231 \\
\hline & & Postgraduate & 0.152 \\
\hline \multirow{6}{*}{ Operation cost overrun } & \multirow{3}{*}{ Undergraduate } & Graduate & 0.007 \\
\hline & & Postgraduate & 0.970 \\
\hline & & Doctorate & 1.000 \\
\hline & \multirow{3}{*}{ Graduate } & Undergraduate & 0.007 \\
\hline & & Postgraduate & 0.113 \\
\hline & & Doctorate & 0.421 \\
\hline
\end{tabular}


International Journal of Mathematical, Engineering and Management Sciences

Vol. 4, No. 2, 289-305, 2019

https://dx.doi.org/10.33889/IJMEMS.2019.4.2-024

\begin{tabular}{|c|c|c|c|}
\hline & \multirow{3}{*}{ Postgraduate } & Undergraduate & 0.970 \\
\hline & & Graduate & 0.113 \\
\hline & & Doctorate & 0.981 \\
\hline & \multirow{3}{*}{ Doctorate } & Undergraduate & 1.000 \\
\hline & & Graduate & 0.421 \\
\hline & & Postgraduate & 0.981 \\
\hline \multirow{12}{*}{ Monopoly of suppliers } & \multirow{3}{*}{ Undergraduate } & Graduate & 0.837 \\
\hline & & Postgraduate & 0.807 \\
\hline & & Doctorate & 0.930 \\
\hline & \multirow{3}{*}{ Graduate } & Undergraduate & 0.837 \\
\hline & & Postgraduate & 0.999 \\
\hline & & Doctorate & 1.000 \\
\hline & \multirow{3}{*}{ Postgraduate } & Undergraduate & 0.807 \\
\hline & & Graduate & 0.999 \\
\hline & & Doctorate & 0.999 \\
\hline & \multirow{3}{*}{ Doctorate } & Undergraduate & 0.930 \\
\hline & & Graduate & 1.000 \\
\hline & & Postgraduate & 0.999 \\
\hline \multirow{12}{*}{ Corruption and bribery } & \multirow{3}{*}{ Undergraduate } & Graduate & 0.997 \\
\hline & & Postgraduate & 0.841 \\
\hline & & Doctorate & 0.897 \\
\hline & \multirow{3}{*}{ Graduate } & Undergraduate & 0.997 \\
\hline & & Postgraduate & 0.515 \\
\hline & & Doctorate & 0.869 \\
\hline & \multirow{3}{*}{ Postgraduate } & Undergraduate & 0.841 \\
\hline & & Graduate & 0.515 \\
\hline & & Doctorate & 1.000 \\
\hline & \multirow{3}{*}{ Doctorate } & Undergraduate & 0.897 \\
\hline & & Graduate & 0.869 \\
\hline & & Postgraduate & 1.000 \\
\hline \multirow{12}{*}{ Insufficient Resources } & \multirow{3}{*}{ Undergraduate } & Graduate & 1.000 \\
\hline & & Postgraduate & 0.994 \\
\hline & & Doctorate & 1.000 \\
\hline & \multirow{3}{*}{ Graduate } & Undergraduate & 1.000 \\
\hline & & Postgraduate & 0.916 \\
\hline & & Doctorate & 1.000 \\
\hline & \multirow{3}{*}{ Postgraduate } & Undergraduate & 0.994 \\
\hline & & Graduate & 0.916 \\
\hline & & Doctorate & 0.993 \\
\hline & \multirow{3}{*}{ Doctorate } & Undergraduate & 1.000 \\
\hline & & Graduate & 1.000 \\
\hline & & Postgraduate & 0.993 \\
\hline \multirow{12}{*}{ Lack of motivation } & \multirow{3}{*}{ Undergraduate } & Graduate & 0.990 \\
\hline & & Postgraduate & 0.928 \\
\hline & & Doctorate & 0.001 \\
\hline & \multirow{3}{*}{ Graduate } & Undergraduate & 0.990 \\
\hline & & Postgraduate & 0.914 \\
\hline & & Doctorate & 0.319 \\
\hline & & Undergraduate & 0.928 \\
\hline & Postgraduate & Graduate & 0.914 \\
\hline & & Doctorate & 0.509 \\
\hline & & Undergraduate & 0.001 \\
\hline & Doctorate & Graduate & 0.319 \\
\hline & & Postgraduate & 0.509 \\
\hline
\end{tabular}


International Journal of Mathematical, Engineering and Management Sciences

Vol. 4, No. 2, 289-305, 2019

https://dx.doi.org/10.33889/IJMEMS.2019.4.2-024

\subsection{Sigma Value for Hypothesis $\mathrm{H} 20$ and $\mathrm{H} 21$}

Calculations are carried out as indicated in the methodology and following are sigma value for hypothesis $\mathrm{H} 20$ and $\mathrm{H} 21$ (Table 5).

Table 5. Sigma for qualification for experience

\begin{tabular}{|c|c|c|c|}
\hline Dependent Variable & $\begin{array}{l}\text { Experience of the } \\
\text { respondents }\end{array}$ & $\begin{array}{l}\text { Experience of the } \\
\text { respondents }\end{array}$ & Sigma \\
\hline \multirow{6}{*}{ Unrealistic time schedule resulting into the delay } & \multirow{2}{*}{0 to 15 years } & 16 to 40 years & 0.999 \\
\hline & & 41 to 50 years & 0.006 \\
\hline & \multirow{2}{*}{16 to 40 years } & 0 to 15 years & 0.999 \\
\hline & & 41 to 50 years & 0.495 \\
\hline & \multirow{2}{*}{41 to 50 years } & 0 to 15 years & 0.006 \\
\hline & & 16 to 40 years & 0.495 \\
\hline \multirow{6}{*}{$\begin{array}{l}\text { Frequent change in scope of work/ Nonclarity on the } \\
\text { scope of work }\end{array}$} & \multirow{2}{*}{0 to 15 years } & 16 to 40 years & 0.980 \\
\hline & & 41 to 50 years & 0.006 \\
\hline & \multirow{2}{*}{16 to 40 years } & 0 to 15 years & 0.980 \\
\hline & & 41 to 50 years & 0.857 \\
\hline & \multirow{2}{*}{41 to 50 years } & 0 to 15 years & 0.006 \\
\hline & & 16 to 40 years & 0.857 \\
\hline \multirow{6}{*}{ Operation cost overrun } & \multirow{2}{*}{0 to 15 years } & 16 to 40 years & 0.230 \\
\hline & & 41 to 50 years & 0.919 \\
\hline & \multirow{2}{*}{16 to 40 years } & 0 to 15 years & $\mathbf{0 . 2 3 0}$ \\
\hline & & 41 to 50 years & 0.807 \\
\hline & \multirow{2}{*}{41 to 50 years } & 0 to 15 years & 0.919 \\
\hline & & 16 to 40 years & 0.807 \\
\hline \multirow{6}{*}{ Monopoly of suppliers } & \multirow{2}{*}{0 to 15 years } & 16 to 40 years & 0.332 \\
\hline & & 41 to 50 years & 0.002 \\
\hline & \multirow{2}{*}{16 to 40 years } & 0 to 15 years & 0.332 \\
\hline & & 41 to 50 years & 0.749 \\
\hline & \multirow{2}{*}{41 to 50 years } & 0 to 15 years & 0.002 \\
\hline & & 16 to 40 years & 0.749 \\
\hline \multirow{6}{*}{ Corruption and bribery } & \multirow{2}{*}{0 to 15 years } & 16 to 40 years & 0.599 \\
\hline & & 41 to 50 years & 0.877 \\
\hline & \multirow{2}{*}{16 to 40 years } & 0 to 15 years & 0.599 \\
\hline & & 41 to 50 years & 0.594 \\
\hline & \multirow{2}{*}{41 to 50 years } & 0 to 15 years & 0.877 \\
\hline & & 16 to 40 years & 0.594 \\
\hline \multirow{6}{*}{ Insufficient resources } & \multirow{2}{*}{0 to 15 years } & 16 to 40 years & 0.718 \\
\hline & & 41 to 50 years & 0.016 \\
\hline & \multirow{2}{*}{16 to 40 years } & 0 to 15 years & 0.718 \\
\hline & & 41 to 50 years & 0.939 \\
\hline & \multirow{2}{*}{41 to 50 years } & 0 to 15 years & 0.016 \\
\hline & & 16 to 40 years & 0.939 \\
\hline \multirow{6}{*}{ Restrictive mind-sets } & \multirow{2}{*}{0 to 15 years } & 16 to 40 years & 0.700 \\
\hline & & 41 to 50 years & 0.874 \\
\hline & 16 to 40 years & 0 to 15 years & 0.700 \\
\hline & & 41 to 50 years & 0.998 \\
\hline & 41 to 50 years & 0 to 15 years & 0.874 \\
\hline & & 16 to 40 years & 0.998 \\
\hline
\end{tabular}


International Journal of Mathematical, Engineering and Management Sciences

Vol. 4, No. 2, 289-305, 2019

https://dx.doi.org/10.33889/IJMEMS.2019.4.2-024

\section{Discussions}

\subsection{Findings for Hypothesis H10 and H11 (Qualification)}

Sigma value for following statements is less than 0.05 . So we reject the null hypothesis and conclude that there is a significant difference in risk perception and barrier through qualifications.

These statements are:

- Unrealistic time schedule resulting into delay: As sigma value for a graduate is 0.266 so there is a significant difference in the mean of this group. The graduate respondent feels the high risk in this statement in comparison to undergraduate respondents.

- Frequent change in scope of work/ Nonclarity on the scope of work: As the sigma-value of undergraduate and graduate is 0.002 so there is a significant difference in the mean of this group. The graduate respondent feels the high risk in this statement in comparison to undergraduate respondents.

- Operation cost overrun: As the sigma-value of undergraduate and graduate is 0.007 so there is a significant difference in the mean of this group. The undergraduate respondent feels the high risk in this statement in comparison to doctorate respondents.

- Lack of motivation: As the sigma value of undergraduate is 0.001 , so there is a significant difference in the mean of this group. The undergraduate respondent feels the high risk in this statement in comparison to other respondents.

\subsection{Findings for Hypothesis $\mathrm{H} 20$ and $\mathrm{H} 21$}

As following statements have sigma-value less than 0.05 so we reject the null hypothesis and conclude that there is a significant difference in risk perception and barrier through experience. These statements are:

- Unrealistic time schedule resulting into delay: As the sigma-value of respondents in having experience 0 to 15 years and 41 to 50 years is 0.006 so there is a significant difference in the mean of this group. The respondent in the experience 41 to 50 years feels the high risk in this statement in comparison to respondents having experience 0 to 15 years.

- Frequent change in scope of work/ Nonclarity on the scope of work: As the sigma-value of respondents having experience 0 to 15 years and 41 to 50 years is 0.006 so there is a significant difference in the mean of this group. The respondents having experience 41 to 50 years feels the high risk in this statement in comparison to respondents having experience 0 to 15 years.

- Operation cost overrun: As the sigma-value of respondents having experience 0 to 15 years and 16 to 40 years is 0.230 so there is a significant difference in the mean of this group. The respondents having experience 0 to 15 and 16 to 40 years feels the high risk in this statement in comparison to respondents having experience 41 to 50 years.

- Monopoly of suppliers: As the sigma-value of respondents having experience 0 to 15 years and 41 to 50 years is 0.002 so there is a significant difference in the mean of this group. The respondents having experience 0 to 15 years feels the high risk in this statement in comparison to respondents having experience 41 to 50 years.

- Insufficient resources: As the sigma-value of respondents having experience 0 to 15 years and 41 to 50 years is 0.016 so there is a significant difference in the mean of this group. The respondents having experience 0 to 15 years feels high barrier in this statement in comparison to respondents having experience 41 to 50 years. 
International Journal of Mathematical, Engineering and Management Sciences

Vol. 4, No. 2, 289-305, 2019

https://dx.doi.org/10.33889/IJMEMS.2019.4.2-024

\section{Conclusion}

This study aimed to understand the effect of qualification and experience of the respondent on the perceptions of the risks and barriers for innovative projects. The outcome of the study underlines that the perception of the risks depends on the qualification and experience of the respondents. Hence during the risk and barriers evaluation in above-mentioned factors to be accounted by project risk and barrier evaluation team.

The output of the study has a robust application for project managers, operations managers. Identification and evaluation of the risks and barriers of the innovative projects is a critical phase to achieve the goal of the projects. The stakeholders of the project are playing important role in risk and barriers evaluation process. Hence the evaluation process of the risks and barriers needs to account the qualification and experience of the expert/ stakeholder. As the success of risks and barrier evaluation is based on the expert's assigned values. Hence risk managers should choose the correct experts.

\section{Limitations and Future Scope}

The contribution of this study is to improve the process of risk management in innovative projects. However, this study is limited to the case of a specific group of people. It also considers limited risks. The proposed method can be tested with other projects with different risks factors with minor modifications.

Further, the effectiveness of the method can be evaluated based on the success rate of the projects. The prosed method can be utilised in different countries along with different projects. In the future, the results can be compared with some alternate method.

\section{Annexure 1. The risk list validated for innovative projects}

\begin{tabular}{|c|c|}
\hline Risk Category & Risk \\
\hline \multirow{5}{*}{ Project } & Unrealistic schedule resulting into the delay \\
\hline & Frequent change in scope of work/ Non-clarity on the scope of work \\
\hline & Unforeseeable design development risks at tender stage \\
\hline & Lack of incompetency of staff working at stakeholders \\
\hline & Project manager competencies \\
\hline \multirow{5}{*}{ Design Risk } & Inadequate design input \\
\hline & Errors in design, detail engineering \\
\hline & Change of design, rework due to change in design \\
\hline & Risk of non-availability of Technological assistance \\
\hline & Lack of technological innovation \\
\hline \multirow{4}{*}{ Financial Risks } & Financial constraints \\
\hline & Operation cost overrun \\
\hline & Inflation in wages, interest rate, etc. \\
\hline & Delay in Payment from customer. \\
\hline \multirow{3}{*}{ Quality } & Stringent Quality requirements \\
\hline & Unrealistic inspection and testing methods proposed in contract \\
\hline & Poor quality of work \\
\hline \multirow{3}{*}{ Labours } & Low productivity of labour and equipment \\
\hline & Delay in the availability of labour, materials, and resources \\
\hline & Lack of qualified staff \\
\hline
\end{tabular}


International Journal of Mathematical, Engineering and Management Sciences

Vol. 4, No. 2, 289-305, 2019

https://dx.doi.org/10.33889/IJMEMS.2019.4.2-024

\begin{tabular}{|c|c|}
\hline Risk Category & Risk \\
\hline \multirow{3}{*}{ Customer } & Delay to furnish and deliver the site to the contractor by the owner/ Customer \\
\hline & Delay in approving mandatory documents by customer \\
\hline & Delay in progress payments by Customer \\
\hline \multirow{3}{*}{ Suppliers } & Delays in sub-contractors work \\
\hline & Frequent change of sub-contractors \\
\hline & Monopoly of Suppliers \\
\hline \multirow{3}{*}{ Materials } & Changes in material types and specification \\
\hline & Shortage of construction materials in market \\
\hline & Material cost \\
\hline \multirow{3}{*}{ Government Policy } & Change in relevant government regulations \\
\hline & Corruption and bribery \\
\hline & Lack of support from government \\
\hline \multirow{3}{*}{ Site-related } & Restricted access at the site \\
\hline & Site accidents \\
\hline & Extreme weather conditions \\
\hline \multirow{3}{*}{ Environment } & Weather effect on Execution \\
\hline & Hazardous materials \\
\hline & Environmental disasters \\
\hline \multirow{3}{*}{ Miscellaneous } & Conflict between stakeholders \\
\hline & Project Stakeholder cooperation and communication \\
\hline & Disastrous events and terrorism \\
\hline
\end{tabular}

\section{Annexure 2. The Barriers list validated for innovative projects}

\begin{tabular}{|l|l|}
\hline \multicolumn{1}{|c|}{ Barrier } & \multicolumn{1}{c|}{ Authors } \\
\hline Insufficient Resources & Santos et al. (2012), Nassar and Faloye (2015) \\
\hline Problems retaining qualified employees & Nassar and Faloye (2015) \\
\hline Unsupportive organizational structure & Wei and Lam (2014) \\
\hline Lack of Competences & Hadjimanolis(1999), Wei and Lam (2014) \\
\hline Inadequate financial means & Nassar and Faloye(2015), Lindkvist et al., 2014) \\
\hline Inadequate R and D, design, testing facilities & Nassar and Faloye (2015), Santos et al. (2012) \\
\hline Lack of motivation & Wei and Lam (2014), Santos et al. (2012) \\
\hline Lack of information on markets & Nassar and Faloye (2015) \\
\hline Restrictive mindsets & Nassar and Faloye (2015) \\
\hline Technological Challenges & Nassar and Faloye(2015), Santos et al. (2012) \\
\hline
\end{tabular}

\section{Conflict of Interest}

All authors have contributed equally in this work. The authors declare that there is no conflict of interest for this publication.

\section{Acknowledgments}

The authors would like to thank all participants in the survey for their active and valuable responses. 
International Journal of Mathematical, Engineering and Management Sciences

Vol. 4, No. 2, 289-305, 2019

https://dx.doi.org/10.33889/IJMEMS.2019.4.2-024

\section{References}

Ahmed, A., Kayis, B., \& Amornsawadwatana, S. (2007). A review of techniques for risk management in projects. Benchmarking: An International Journal, 14(1), 22-36.

Ajmal M., Malik M., \& Saber, H. (2017). Factor analyzing project management practices in the United Arab Emirates. International Journal of Managing Projects in Business, 10(4), 749-769.

Banerjee, S., Srivastava, D. K., \& Raut, R. D. (2011). Structuring for innovation-a review. International Journal of Business Excellence, 4(5), 595-620.

Bowers, J., \& Khorakian, A. (2014). Integrating risk management in the innovation project. European Journal of Innovation Management, 17(1), 25-40.

Cloutier, A. (2012). Determinants of innovation for property and casualty insurers. International Journal of Business Research, 12(1), 51-68.

Damanpour, F. (1991). Organizational innovation: a meta-analysis of effects of determinants and moderators. Academy of Management Journal, 34(3), 555-590.

Dandage, R., Mantha, S. S., \& Rane, S. B. (2018). Ranking the risk categories in international projects using the TOPSIS method. International Journal of Managing Projects in Business, 11(2), 317-331.

Elkington, P., \& Smallman, C. (2002). Managing project risks: a case study from the utilities sector. International Journal of Project Management, 20(1), 49-57.

Fan, M., Lin, N. P., \& Sheu, C. (2008). Choosing a project risk handling strategy-an analytical model, International Journal of Production Economics, 112(2), 700-713.

Gassmann, O., \& Han, Z. (2004). Motivations and barriers of foreign R\&D activities in China. $R \& D$ Management, 34(4), 423-437.

Guo, Y. (2013). Risk management of uncertain innovation project based on Bayesian risk decision. International Journal of Engineering and Applied Sciences, 4(3), 31-39.

Hadjimanolis A. (1999). Barriers to innovation for SMEs in a small less developed country (Cyprus). Technovation, 19(9), 561-570.

Hernandez-Gonzalez, Y., Garcı-Moreno, C., Rodriguez-Garcıa, M. A., Valencia-Garcıa, R., \& GarcıaSanchez, F. (2014). A semantic-based platform for R\&D project funding management. Computers in Industry, 65(5), 850-861.

Isaac, I. (1995). Training in risk management. International Journal of Project Management, 13(4), 225-229.

Jannadi, O. A., \& Almishari, S. (2003). Risk assessment in construction. Journal of Construction Engineering and Management, 129(5), 492-500.

Kwak, Y. H., \& LaPlace, K. S. (2005). Examining risk tolerance in project-driven organization. Technovation, 25(6), 691-695.

Lindkvist, C., Karlsson, A., Sornes, K., \& Wyckmans, A. (2014). Barriers and challenges in nZEB projects in Sweden and Norway. Energy Procedia, 58(1), 199-206.

Luppino, R., Hosseini, M. R., \& Rameezdeen, R. (2014). Risk management in research and development (R\&D) projects: the case of South Australia. Asian Academy of Management Journal, 19(2), 67-85.

Marcelino-Sádaba, S., Pérez-Ezcurdia, A., Echeverría Lazcano, A. M., \& Villanueva, P. (2014), Project risk management methodology for small firms. International Journal of Project Management, 32(2), 327340 .

Mu, J., Peng, G., \& MacLachlan, D. L. (2009). Effect of risk management strategy on NPD performance. Technovation, 29 (3), 170-180. 
International Journal of Mathematical, Engineering and Management Sciences

Vol. 4, No. 2, 289-305, 2019

https://dx.doi.org/10.33889/IJMEMS.2019.4.2-024

Nassar M. L., \& Faloye D. O. (2015). Barrier to innovation in developing countries firms: evidence from nigerian small and medium scale enterprises. European Scientific Journal, 11(19), 196-213.

Oliva, F. L., (2014). Knowledge management barriers, practices and maturity model. Journal of Knowledge Management, 18(6), 1053-1074.

Oliva, F. L., Sobral, M. C., Santos, S. A., Almeida, M. I. R., \& Grisi, C. C. H. (2011). Measuring the probability of innovation in technology-based companies. Journal of Manufacturing Technology Management, 22(3), 365-383.

Palm, K., \& Lindahl, M. (2015). A project as a workplace: observations from project managers in four R\&D and project-intensive companies. International Journal of Project Management, 33(4), 828-838

Rudnik, K., \& Deptula, A. M. (2015). System with probabilistic fuzzy knowledge base and parametric inference operators in risk assessment of innovative projects. Expert Systems with Applications, 42(1718), 6365-6379.

Santos, F. R. S. D., \& Cabral, S. (2008). FMEA and PMBOK applied to project risk management. Journal of Information Systems and Technology Management, 5(2), 347-364

Santos, V. R., Soares, A. L., \& Carvalho, J. A. (2012). Knowledge sharing barriers in complex research and development projects: an exploratory study on the perceptions of project managers. Knowledge and Process Management, 19(1) 27-38.

Sato. T., \& Hirao, M. (2013). Optimum budget allocation method for projects with critical risks. International Journal of Project Management, 31(1) 126-135

Schumpeter, J. A. (1934). The theory of economic development: an inquiry into profits, capital, credit, interest, and the business cycle (English translation). Cambridge: Harvard University Press.

Stewart, R. W., \& Fortune, J. (1995). Application of systems thinking to the identification, avoidance, and prevention of risk. International Journal of Project Management, 13(5), 279-286

Teberga P. M. F., \& Oliva F. L. (2018). Identification, analysis and treatment of risks in the introduction of new technologies by start-ups. Benchmarking: An International Journal, 25(5), 1363-1381.

Teece, D. J. (1986). Profiting from technological innovation: implications for integration, collaboration, licensing and public policy. Research Policy, 15(6), 285-305.

Turner, J. R., Ledwith, A., \& Kelly, J. (2010). Project management in small to medium sized enterprises: matching processes to the nature of the firm. International Journal of Project Management, 28(8), 744755.

Wang, J., Lin, W., \& Huang, Y. H. (2010). A performance-oriented risk management framework for innovative R\&D projects. Technovation, 30(11-12), 601-611.

Ward, S., \& Chapman, C. (2003). Transforming project risk management into project uncertainty management. International Journal of Project Management, 21(2), 97-105.

Wei, Y., \& Lam, P. T. (2014). Innovation barriers at the project level: study of a UK construction firm. International Journal of Architecture, Engineering and Construction, 3(3), 182-194.

Witte, E. (1977). Power and innovation: a two-center theory. International Studies of Management and Organization, 7(1), 47-70.

Zhang Y., \& Fan Z. P. (2014). An optimization method for selecting project risk response strategies. International Journal of Project Management, 32(3), 412-422.

Zhang, Y. (2016). Selecting risk response strategies considering project risk interdependence. International Journal of Project Management, 34(5), 819-830. 
International Journal of Mathematical, Engineering and Management Sciences

Vol. 4, No. 2, 289-305, 2019

https://dx.doi.org/10.33889/IJMEMS.2019.4.2-024

Zwikael, O., \& Ahn, M. (2011). The effectiveness of risk management: an analysis of project risk planning across industries and countries. Risk Analysis: An International Journal, 31(1), 25-37.

Zwikael, O., \& Sadeh, A. (2007). Planning effort as an effective risk management tool. Journal of Operation Management, 25(4), 755-767.

Zwikael, O., Pathak, R. D., Singh, G., \& Ahmad, S. (2014). The moderating effect of risk on the relationship between planning and success. International Journal of Project Management, 32(3), 435-441. 